\title{
Lipids of Peripheral Nerve
}

\author{
By A. C. JOHNSON (National Research Council Fellow), A. R. McNABB (National Research \\ Council Fellow) AND R. J. ROSSITER, Department of Biochemistry, University of Western Ontario, \\ London, Canada
}

(Received.27 April 1948)

In order to study experimentally the changes which occur in the distribution of the lipids in a peripheral nerve when it undergoes degeneration, methods had to be developed which demanded only a small sample of tissue. In this paper the application of the methods at present in use in this laboratory to normal peripheral nerve is described.

\section{METHODS}

Analyses were made on the sciatic nerves of 3 rabbits, 4 cats, 3 dogs and a beaver, and on the sciatio nerves or emoral nerves of a number of humans. The nerve was dissected out as soon as possible after death and the lipids were extracted and estimated by the methods described previously (Johnson, McNabb \& Rossiter, 1948). The concentration of free cholesterol, total cholesterol, cerebroside, total phospholipid, monoaminophospholipid and lecithin was measured directly, and, from these figures, the values for ester cholesterol, sphingomyelin and kephalin were calculated.

\section{RESULTS}

The concentration of 'essential lipid ',i.e. cerebroside, cholesterol and phospholipid, for each nerve studied is given in Table 1 , and the concentration of lecithin, sphingomyelin and kephalin, the individual phospholipids which go to make up the total phospho- lipid fraction, in Table 2. The figures in each of these tables are in terms of $\mathrm{mg} . / 100 \mathrm{mg}$. fresh tissue. In Table 3, each of the lipid fractions is given as a percentage of the 'essential lipid', while in Table 4 each of the individual phospholipids-lecithin, sphingomyelin and kephalin-is given as a percentage of the total phospholipid.

\section{DISCUSSION}

The classical work on the distribution of the lipids in peripheral nerve is that of Falk (1908), who found the following relative concentrations of lipid in medullated nerve: cholesterol, 25.0; kephalin, 12.4; lecithin, 2.9; and cerebroside, 18.2. In the present investigation, in which more refined methods have been used for determining the distribution of the lipids, the results are considerably different.

Randall (1938), in a study of human nerve, found that the concentration of phospholipid was $4 \cdot 5$, cholesterol 1.5 and cerebroside $1.6 \%$, referred to wet weight. In general our results for human nerve substantiate those of Randall, but the latter did not attempt to distinguish between the various phos: pholipid fractions. In most of the human nerves studied, the concentration of the various lipids was found to be slightly less than that reported by

Table 1. Lipids in peripheral nerve (expressed as $\mathrm{mg} . / 100 \mathrm{mg}$. fresh tissue)

Rabbit 1 (S)

Rabbit 2 (S)

Rabbit 3 (S)

Cat 1 (S)

Cat 2 (S)

Cat 3 (S)

Cat 4 (S)

$\operatorname{Dog} 1$ (S)

Dog 2 (S)

Dog 3 (S)

Beaver 1 (S)

Patient 1 (S)

Patient 2 (F)

Patient 3 (S)

Patient 3 (F)

Patient 4 (S)

Patient 4 (F)

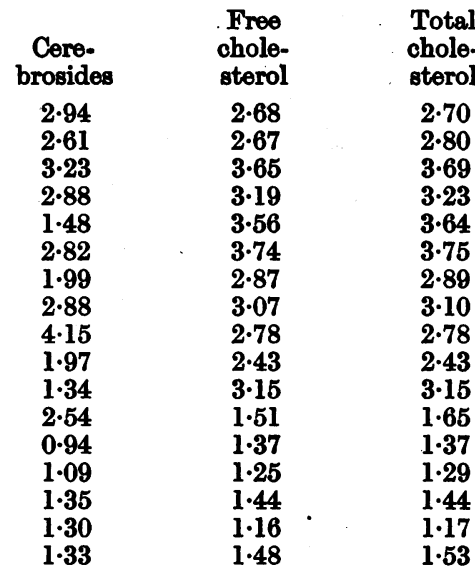

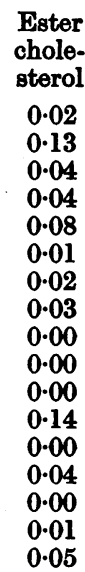

$\mathrm{S}=$ sciatic nerve; $\mathrm{F}=$ femoral nerve.

\begin{tabular}{|c|c|}
\hline $\begin{array}{l}\text { Total } \\
\text { hospho- } \\
\text { lipid }\end{array}$ & $\begin{array}{l}\text { 'Essenti } \\
\text { lipid' }\end{array}$ \\
\hline $\begin{array}{l}\mathbf{5} \cdot 21 \\
\mathbf{5} \cdot 79 \\
\mathbf{6} \cdot 81 \\
\mathbf{6} \cdot 21 \\
\mathbf{5} \cdot 88 \\
\mathbf{7} \cdot 27 \\
\mathbf{6} \cdot 28 \\
\mathbf{5} \cdot 39 \\
\mathbf{5} \cdot 14 \\
\mathbf{5} \cdot 62 \\
\mathbf{5} \cdot 85 \\
\mathbf{3} \cdot 81 \\
\mathbf{2} \cdot 22 \\
\mathbf{3} \cdot 09 \\
\mathbf{2 \cdot 9 7} \\
\mathbf{2} \cdot 40 \\
\mathbf{3} \cdot 32\end{array}$ & $\begin{array}{r}10 \cdot 85 \\
11 \cdot 20 \\
13 \cdot 73 \\
12 \cdot 32 \\
11 \cdot 00 \\
13 \cdot 84 \\
11 \cdot 16 \\
11 \cdot 37 \\
12 \cdot 07 \\
10 \cdot 02 \\
10 \cdot 34 \\
8 \cdot 00 \\
4 \cdot 53 \\
5 \cdot 47 \\
5 \cdot 76 \\
4 \cdot 87 \\
6 \cdot 18\end{array}$ \\
\hline
\end{tabular}


Table 2. Phospholipids in peripheral nerve (expressed as $\mathrm{mg} . / 100 \mathrm{mg}$. fresh tissue)

Rabbit 1 (S)

Rabbit 2 (S)

Rabbit 3 (S)

Cat 1 (S)

Cat 2 (S)

Cat 3 (S)

Cat 4 (S)

$\operatorname{Dog} 1$ (S)

Dog 2 (S)

Dog 3 (S)

Beaver 1 (S)

Patient 1 (S)

Patient 2 (F)

Patient 3 (S)

Patient 3 (F)

Patient 4 (S)

Patient 4 (F)

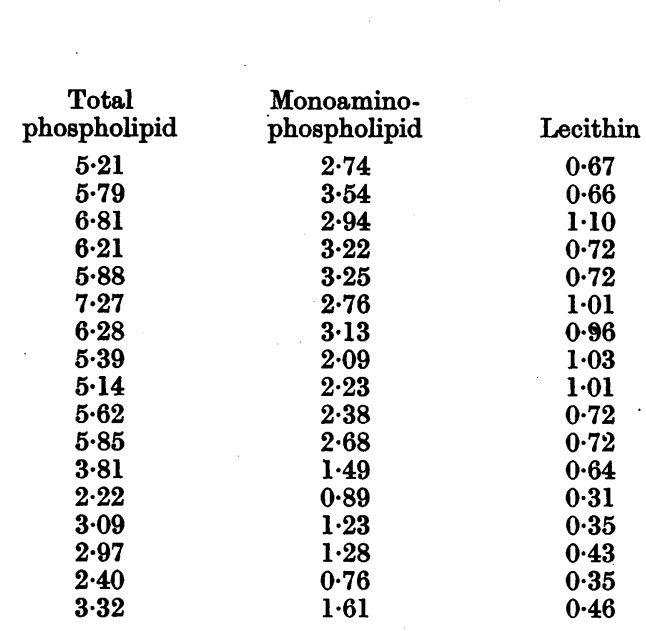

Sphingomyelin
(total phos-
pholipid less
monoamino-
phospholipid)
$2 \cdot 47$
$2 \cdot 25$
$\mathbf{3} \cdot 87$
$2 \cdot 99$
$2 \cdot 63$
$4 \cdot 51$
$3 \cdot 15$
$3 \cdot 30$
$2 \cdot 91$
$3 \cdot 24$
$3 \cdot 17$
$2 \cdot 32$
$1 \cdot 33$
$1 \cdot 86$
$1 \cdot 69$
$1 \cdot 64$
$1 \cdot 71$

Kephalin (monoaminophospholipid less lecithin)

$\mathbf{2} \cdot 07$
$2 \cdot 88$
$1 \cdot 84$
$2 \cdot 50$
$2 \cdot 53$
$1 \cdot 75$
$2 \cdot 17$
$1 \cdot 06$
$1 \cdot 22$
$1 \cdot 66$
$1 \cdot 96$
$0 \cdot 85$
0.58
$0 \cdot 88$
$0 \cdot 85$
$0 \cdot 41$
$1 \cdot 15$
$2 \cdot 88$

$1 \cdot 84$

$2 \cdot 50$

$1 \cdot 75$

$2 \cdot 17$

1.22

$1 \cdot 66$

1.96

$0 \cdot 58$

$0 \cdot 88$

0.41

$1 \cdot 15$

$S=$ sciatic nerve; $F=$ femoral nerve.

Table 3. Distribution of lipids in peripheral nerve (expressed as percentage of 'essential lipid')

\begin{tabular}{|c|c|c|c|c|c|c|}
\hline & $\begin{array}{c}\text { Cere- } \\
\text { broside }\end{array}$ & $\begin{array}{l}\text { Total } \\
\text { chole- } \\
\text { sterol }\end{array}$ & $\begin{array}{l}\text { Total } \\
\text { phospho- } \\
\text { lipid }\end{array}$ & Lecithin & $\begin{array}{c}\text { Sphingo- } \\
\text { myelin }\end{array}$ & Kephalin \\
\hline Rabbit.1 (S) & $27 \cdot 1$ & $24 \cdot 9$ & $48 \cdot 0$ & $6 \cdot 2$ & $22 \cdot 8$ & $19 \cdot 0$ \\
\hline Rabbit 2 (S) & $23 \cdot 3$ & $25 \cdot 0$ & $51 \cdot 7$ & $6 \cdot 0$ & $20 \cdot 3$ & $25 \cdot 4$ \\
\hline Rabbit 3 (S) & $23 \cdot 6$ & $26 \cdot 8$ & $49 \cdot 6$ & $8 \cdot 2$ & $27 \cdot 9$ & $13 \cdot 5$ \\
\hline Cat 1 (S) & $23 \cdot 4$ & $26 \cdot 2$ & $50 \cdot 4$ & $5 \cdot 8$ & $24 \cdot 1$ & 20.5 \\
\hline Cat 2 (S) & $13 \cdot 4$ & $\mathbf{3 3} \cdot \mathbf{1}$ & $53 \cdot 5$ & $6 \cdot 6$ & 23.9 & $23 \cdot 0$ \\
\hline Cat 3 (S) & $20 \cdot 6$ & $26 \cdot 5$ & $52 \cdot 9$ & $7 \cdot 4$ & $32 \cdot 8$ & $12 \cdot 7$ \\
\hline Cat 4 (S) & $17 \cdot 8$ & $25 \cdot 9$ & $56 \cdot 3$ & $8 \cdot 5$ & $28 \cdot 4$ & $19 \cdot 4$ \\
\hline $\operatorname{Dog} 1$ (S) & $25 \cdot 3$ & $27 \cdot 3$ & $47 \cdot 4$ & $9 \cdot 1$ & $29 \cdot 0$ & $9 \cdot 3$ \\
\hline Dog 2 (S) & $34 \cdot 4$ & $23 \cdot 0$ & $42 \cdot 6$ & $8 \cdot 4$ & $24 \cdot 1$ & $10 \cdot 1$ \\
\hline Dog 3 (S) & $19 \cdot 7$ & $24 \cdot 2$ & $56 \cdot 1$ & $7 \cdot 2$ & $32 \cdot 4$ & $16 \cdot 5$ \\
\hline Beaver 1 (S) & $13 \cdot 0$ & $30 \cdot 4$ & $56 \cdot 6$ & $6 \cdot \overline{9}$ & $30 . \overline{8}$ & $18 \cdot 9$ \\
\hline Patient 1 (S) & $31 \cdot 7$ & $20 \cdot 7$ & $47 \cdot 6$ & $7 \cdot 8$ & $29 \cdot 1$ & $10 \cdot 7$ \\
\hline Patient 2 (F) & $20 \cdot 9$ & $30 \cdot 2$ & $48 \cdot 9$ & $6 \cdot 7$ & $29 \cdot 4$ & $12 \cdot 8$ \\
\hline Patient 3 (S) & $19 \cdot 7$ & $24 \cdot 3$ & $56 \cdot 0$ & $5 \cdot 9$ & 33.9 & $16 \cdot 2$ \\
\hline Patient 3 (F) & $23 \cdot 3$ & $25 \cdot 1$ & $51 \cdot 6$ & $7 \cdot 5$ & $29 \cdot 4$ & $14 \cdot 7$ \\
\hline Patient 4 (S) & $26 \cdot 6$ & $24 \cdot 1$ & $49 \cdot 3$ & $7 \cdot 1$ & $33 \cdot 8$ & $8 \cdot 4$ \\
\hline Patient 4 (F) & $21 \cdot 5$ & $24 \cdot 8$ & $53 \cdot 7$ & $7 \cdot 4$ & $27 \cdot 7$ & $18 \cdot 6$ \\
\hline
\end{tabular}

Randall. However, our material came from older patients, the ages of the four patients studied being $54,68,74$ and 45 years. Randall has reported that, in diabetic and arteriosclerotic gangrene, there is a decrease in the concentration of each of the 'essential lipid' constituents of nerve, an observation confirmed by us for other degenerative conditions.

Another point to consider is that the material studied came from the proximal end of the nerve, where the nerve is large and the incorporated fibrous connective tissue much greater. This, we feel, explains why, on a wet weight basis, the concentration of 'essential lipid' in human nerve was found to be less than that of the rabbit, cat, dog and beaver, where the nerves were smaller and connective tissue less.
Despite the fact that the concentration of each of the lipid fractions was found to be less in human nerves, the distributions of the three fractions which make up the 'essential lipids', and of the individual phospholipids, were very similar in the human and animal nerves.

There are few data in the literatune for the distribution of the lipids in the peripheral nerves of the rabbit, cat, dog and beaver. Schmidt, Benotti, Hershman \& Thannhauser (1946) estimated total phospholipid and monoaminophospholipid concentration in three cat nerves. They found $7 \cdot 5,8 \cdot 6$ and $8.3 \%$ phospholipid, of which $50,44.5$ and $44.5 \%$ was sphingomyelin; these figures are of the same order as ours. They also found that sphingomyelin formed only $20 \%$ of the total phospholipid in rat 
nerve, a value lower than that for any of the species investigated in the present study.

Table 4. Distribution of phospholipids in peripheral nerve (expressed as percentage of total phospholipid)

\begin{tabular}{|c|c|c|c|}
\hline & $\begin{array}{c}\text { Lecithin } \\
(\%)\end{array}$ & $\begin{array}{c}\text { Sphingo- } \\
\text { myelin } \\
(\%)\end{array}$ & $\begin{array}{c}\text { Kephalin } \\
(\%)\end{array}$ \\
\hline Rabbit 1 (S) & 12.9 & $\begin{array}{l}47 \cdot 4 \\
38 \cdot 0\end{array}$ & $\begin{array}{l}39 \cdot 7 \\
49 \cdot 7\end{array}$ \\
\hline Rabbit 2 (S) & $11 \cdot 4$ & $38 \cdot 9$ & $49 \cdot 7$ \\
\hline Rabbit 3 (S) & $16 \cdot 2$ & $56 \cdot 8$ & $27 \cdot 0$ \\
\hline Cat 1 (S) & $11 \cdot 6$ & $48 \cdot 2$ & $40 \cdot 2$ \\
\hline Cat 2 (S) & $12 \cdot 2$ & $44 \cdot 8$ & $\mathbf{4 3} \cdot 0$ \\
\hline Cat 3 (S) & $14 \cdot 0$ & $62 \cdot 0$ & $24 \cdot 0$ \\
\hline Cat 4 (S) & $15 \cdot 2$ & $50 \cdot 3$ & $\mathbf{3 4 \cdot 5}$ \\
\hline $\operatorname{Dog} 1(\mathbf{S})$ & $19 \cdot 1$ & $61 \cdot 2$ & $19 \cdot 7$ \\
\hline Dog 2 (S) & $19 \cdot 6$ & $56 \cdot 6$ & $23 \cdot 8$ \\
\hline $\operatorname{Dog} 3$ (S) & $12 \cdot 8$ & $57 \cdot 7$ & $29 \cdot 5$ \\
\hline Beaver 1 (S) & $12 \cdot 3$ & $54 \cdot 4$ & 33.3 \\
\hline Patient 1 (S) & $16 \cdot 5$ & $61 \cdot 1$ & $22 \cdot 4$ \\
\hline Patient 2 (F) & $13 \cdot 6$ & $60 \cdot 2$ & $26 \cdot 2$ \\
\hline Patient 3 (S) & $11 \cdot 3$ & $60 \cdot 2$ & $28 \cdot 5$ \\
\hline Patient 3 (F) & $14 \cdot 5$ & $\mathbf{5 7 \cdot 0}$ & $28 \cdot 5$ \\
\hline Patient 4 (S) & $14 \cdot 5$ & $68 \cdot 4$ & $17 \cdot 1$ \\
\hline Patient 4 (F) & $13 \cdot 8$ & 51.5 & $\mathbf{3 4} \cdot 7$ \\
\hline
\end{tabular}

The relative distribution of cerebroside, chole. sterol and phospholipid was roughly $1: 1: 2$ in peripheral nerves of all the species studied. This is also roughly the distribution of the 'essential lipids' in brain tissue of the same species (Johnson et al. 1948). When one examines the distribution of the various constituents of the phospholipid fraction, however, a difference between peripheral nerve and brain tissue becomes apparent. In all the species studied $50-70 \%$ of the phospholipid of peripheral nerve is sphingomyelin, wheress the corresponding figure for whole brain tissue is $20 \%$. The figure is $40 \%$ for brain white matter, however, and in general the distribution of all the lipid constituents of peripheral nerve bears a much greater resemblance to the lipid distribution in the white matter of the brain than to either that of the grey matter or that of the brain as a whole. This is particularly apparent when the lipids are presented as percentages of total 'essential lipid', and it is, perhaps, hardly surprising when one considers that a high percentage of the lipids in both the white matter of the brain and in peripheral nerve go to make up the 'myelin' sheath. The ohief difference between the lipid distribution in peripheral nerve and that in white matter of the brain is that, in peripheral nerve the percentage of sphingomyelin is somewhat greater, while the percentage of kephalin and cerebroside is somewhat less.

\section{SUMMARY}

1. The cerebroside, free cholesterol, total cholesterol, total phospholipid, lecithin, sphingomyelin and kephalin concentrations in peripheral nerves from the rabbit, cat, dog, beaver and man have been determined.

2. The distribution of the 'essential lipids' (cerebrosides, total cholesterol and total phospholipid) and of the individual phospholipids more closely resembles the distribution in the white matter of the brain than that in either the grey matter or whole brain. In peripherel nerve, however, there is relatively more sphingomyelin and less kephalin and cerebroside than in brain white matter.

This work was aided by a grant from the National Research Council of Canada. Thanks are due to Mr Norval Burt for skilful technical assistance.

\section{REFERENCES}

Falk, F. (1908). Biochem. Z. 13, 153.

Johnson, A. C., MoNabb, A. R. \& Rossiter, R. J. (1948). Biochem. J. 43, 573.
Randall, L. O. (1938). J. biol. Chem. 125, 723.

Schmidt, G., Benotti, J., Hershman, B. \& Thannhauser, S. J. (1946). J. biol. Chem. 166, 505. 